\title{
12 \\ Opening the Paths to Healing
}

During our final two months in Timor-Leste, I was immersed in documenting the practices and knowledge of specialist and everyday healers in Baucau and its hinterlands. In previous research trips, we had usually left the children at home with their cousins, but now they were older we encouraged them to come with us so they could experience a greater breadth of Timorese life. One of our first visits was to the house of Senhor Januario whose home is in a village on the plateau above Bercoli. Januario da Silva is a renowned local bone healer. Himself an avid cockfighter, he maintains that he learnt his craft by healing cockerel injured from fighting. In the Indonesian era, his first patient was an Indonesian soldier injured during a soccer match. But the military doctors had been angered by his intervention and he was discouraged from continuing. Then, around the time of independence, he had healed a man who was shot in the arm by the Indonesian military. Since then, his fame had spread through the region and he was now in demand to treat many musculoskeletal injuries. He also remains an avid cockfighter.

Senhor Januario's healing practice involved massage and the application of water infused with small fragments of 11 secret botanical species that he harvested from the forest. Januario says that his healing power came from a dream. His traditional bamboo-and-thatch 'clinic' was frequently brimming with local people who had been involved in vehicle accidents. He told us that, after a large accident in the area, it is not uncommon for microlets (local minivan transport) to arrive at the clinic laden with patients 
requesting his treatment. Even the local hospital would sometimes refer people to him rather than to the larger regional hospital. He is able to maintain his practice without any support from the formal health system.

When we arrived at his clinic, consultations on the bamboo daybed at the front of the house by the road were in full swing. Januario was massaging and gently manipulating the shoulder of a young man who had broken his arm in a motorbike accident. When the injury occurred three months ago in Dili, he had been treated there by a healer in the capital. However, the break had not mended well, and he remained in chronic pain. He had travelled the two hours from his village to see Januario. Several other inpatients of the clinic also awaited treatment. A woman who had been there for two months had sustained a serious injury on her lower leg, also from a motorbike accident. Another woman from the mountains of Matebian had broken her leg falling out of a pomelo tree. She had been in the clinic for six weeks. Shortly after we arrived, a young local girl with a broken arm walked in. 'This one broke her arm dancing,' joked Januario. It turned out she had slipped when washing the dishes at a wedding celebration.

The newest patient at the clinic that day was a young man who had arrived two days earlier with an injury to his lower leg. Januario introduced him and quickly pointed to another bamboo house next door. 'That's where his younger brother is,' he tells us. 'He has much more serious injuries.' We were taken to see the brother who lay prone on a bamboo bed. His still-bloodied lower leg was strapped with bamboo splints and tied with lengths of cloth where the tibia had snapped. 'He will need to be here for the next four months,' said Januario calmly.

The boy, Salvador, smiled at us weakly and turned down the music playing through his smartphone. He explained that two days previous he had been riding pillion on his brother's motorbike back to his village so that he could sort out his electoral card documentation. (He was planning to apply for a Portuguese passport that would allow him to work in Europe.) As they made their way up the final stretch of a windy mountain road, they found themselves head-on with a bus coming from the opposite direction. The drunk bus driver was on the wrong side of the road. On impact, Salvador's leg slammed into the steps of the bus. Salvador's family had brought him straight to Senhor Januario. No one even thought of taking him to the hospital. There, people say, such a severe injury would result in an amputation, and so it's better to keep well away. 


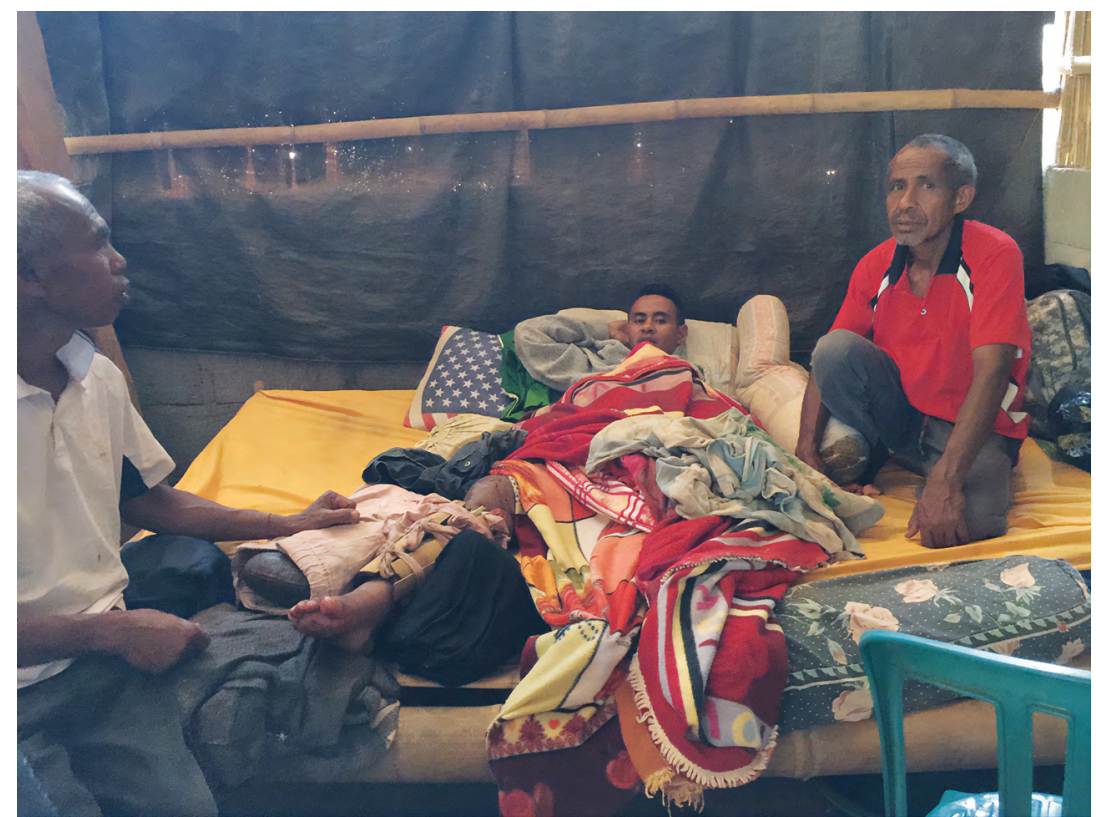

\section{Photo 45: Januario's clinic with Salvador and his father.}

The day before, the police and the owner of the bus had visited the clinic and the bus owner had promised to pay the costs of the boy's treatment, including the cost of antibiotics that Senhor Januario had sourced from contacts within the formal health system to treat infection. Salvador's father, who was sleeping by his side during the months of treatment, held great faith in Senhor Januario. 'He uses only water to treat people,' he said, to assure us that Senhor Januario was not a healer of the dark arts. Senhor Januario and his patients repeated that his treatments involved only manipulations and water. He kept a small bottle of water next to him to use as a part of the massage treatment. The seriously injured boy would have his legged unwrapped and treated regularly with this water.

Away from the clinic, other stories of Senhor Januario's healing powers and practices emerged. I was frequently told by those who know him that Januario relies on other healing powers beyond the use of water. They say his healing knowledge comes from his communication with a great snake-a snake whose life he saved and who has now bequeathed to him the knowledge of bone healing (and botanical medicine). The story goes that Senhor Januario was out with an Indonesian hunting party one day when someone in the party came across a water python and severed its 
body in two. Aghast at this act, Senhor Januario circled back alone to recover the two parts of the python and sew them back together. Because of this redemptive act, he now has access to the python's power.

Various villagers tell me that Januario's healing is enabled by this dai (nature spirit). At night-time, the water python slithers into bed with Januario's patients and wraps itself around their limbs to fuse the bones and assist Januario in the massage process. The botanical residues in the special water function to call the snake's assistance. But patients must be careful to avoid eating garlic during this treatment, they say. Garlic repels snakes.

On another occasion, we travelled to meet Joaquin and Palmira, a husband and wife team of healers, in a remote valley in the hinterland of Bercoli. This time I was accompanied by the director of the local health clinic. We talked about healers in the region and I asked whether or not there are any direct links between them and the formal health system. 'Not really,' he said. 'But we do encourage people to consult with customary healers according to their fiar (trust or belief).' He explained that in Timor-Leste there are two main types of specialist healers, with some crossover between the two. There are those who consult directly with the spirit world and then there are those who understand well the healing properties of plants. He said that the latter healers are particularly useful to know more about because they may offer an opportunity to modernise Timorese medicine. I am intrigued to learn more about how the ancient and modern might combine.

Arriving at the couple's property, we sat in the shade of their origin house. We had met Joaquin the year before at the house of my research counterpart, retired mental health nurse Senhor Almeida. Joaquin's father lived next door to Senhor Almeida in the town of Venilale. The families knew each other well and Joaquin had, at the time, successfully treated Senhor Almedia's wife for a gallstone aliment that had failed to respond to treatment at the local health clinic. Joaquin was something of a mystic healer and his healing practice was quite esoteric and, during that first meeting at least, very difficult to comprehend. His wife, Palmira, was immediately much warmer and open. After she had prepared coffee and snacks, she took us enthusiastically through many of the plant treatments she commonly uses. She explained the process of harvesting forest 
medicines and how she and her husband would trial these medicines and observe the effects on each other before offering such treatments to others. Given her enthusiasm, we arranged to return another day to observe her treating her patients. On the agreed day, to our surprise, she had gathered together about a dozen of her patients, most of them family, from all around the valley. Many told us they had walked hours to be there, some carrying small babies. Like Senhor Almeida's wife, most had first sought treatment unsuccessfully at the local health clinic. They clearly thought highly of Palmira and her practice.

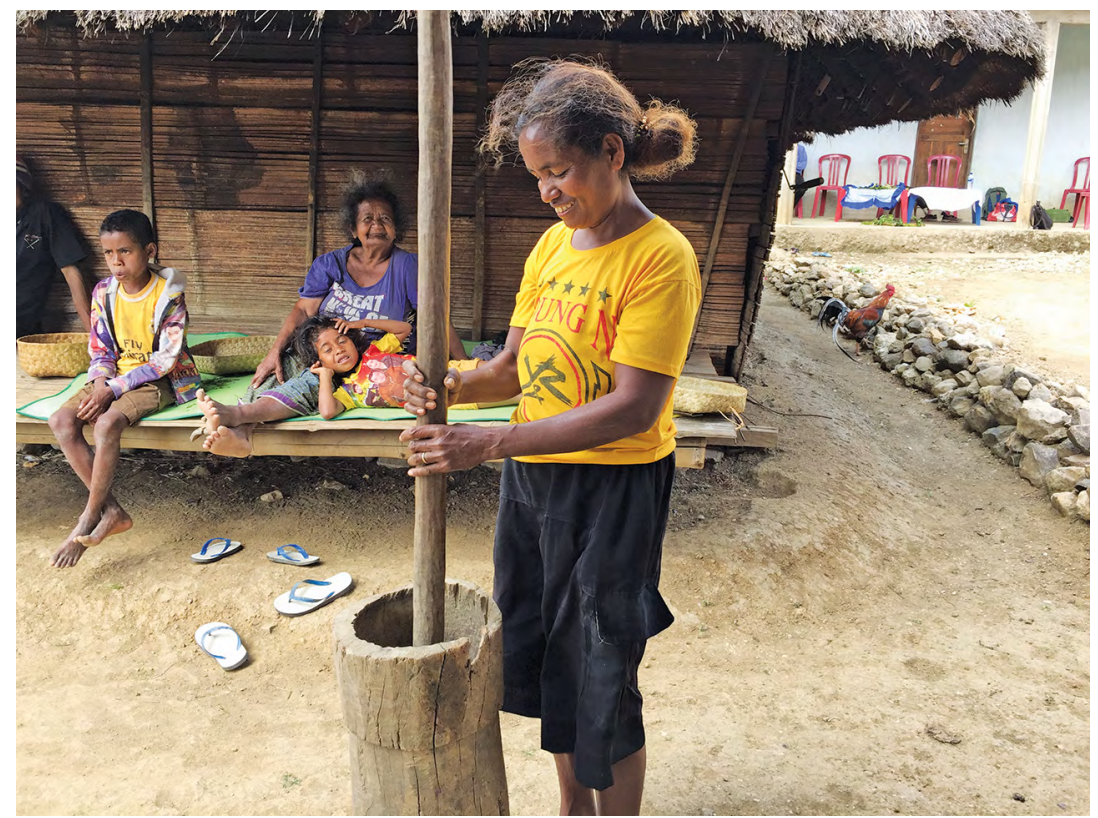

Photo 46: Palmira pounding forest medicine.

A week or so later, we headed deeper into the mountains to meet another healer reputed to be very knowledgeable about the healing properties of plants. He, like Joaquin, was also understood to heal via his intimate access to the power of nature spirits. We were accompanied once again by Senhor Almeida. Senhor Almeida is a renowned institution in the region and seemingly loved by everyone. He first learnt his nursing practice in the jungle as a resistance fighter, later returning to civilian life and dedicating his working life to healing others. He had not wanted to retire, but his hand was forced by his advancing age. The problem was that no one seemed to know or trust his replacement, and so Senhor Almeida 
continued to receive requests for house visits. He had, over his years of practice, cultivated both a deep respect for customary healing practices and traditions and a passion to find ways to better engage them with the formal health system.

This meeting had been set up for us by the health clinic director in a house where Senhor Almeida had never been. As we drove along the red dirt road skirting the craggy Ariana mountain ridge, the views across to the main Matebian mountain range and down the river valley across to the sea were stunning. The bamboo and concrete houses in the area were bathed in sunlight, a welcome change to the fog and damp that envelops this area for much of the year. Everything that day seemed to be sparkling, lush, cool and green. We stopped at a house for directions and were pointed towards the 'teacher's house'. The healer lived nearby.

The village was nestled amid a beautiful grove under the eastern peaks of Mount Ariana. In the 1990s, a giant statue of Our Lady had been erected on the top of the mountain. On clear days during the rice harvest season in the Wai Daba valley below, we had been able to see a gleaming white object rising up from the peak. Noyti's kids were always angling for us to drive them there so we could all climb to the top for a photo opportunity. The Old Lady was far less keen on the idea. As her own origin house hailed from this mountain area, she knew that the peaks were a site of great lulik power and that the statue was now interfering with their force. Why else, she argued, would the statue have been twice struck by lightning and badly damaged?

Somebody went to fetch the healer, Senhor Domingos, and when he came down to meet us he directed our vehicle up a steep narrow path where we found a house and yard full of people. Tarpaulins were draped in a marquee arrangement out the front, and many people were gathered underneath, some eating and others working on what looked to be carpentry. A monument of sorts was under construction just uphill on the other side of the house. We could also make out many more people seated inside around a long table that was covered in a tais. We were invited to take our place on the seating on the veranda. Many men quickly gathered to sit with us. All this activity made me think that somebody must have died, and that we had arrived during the early stages of a mate uma (death house). What an unfortunate time to arrive for an interview, I ruminated. 


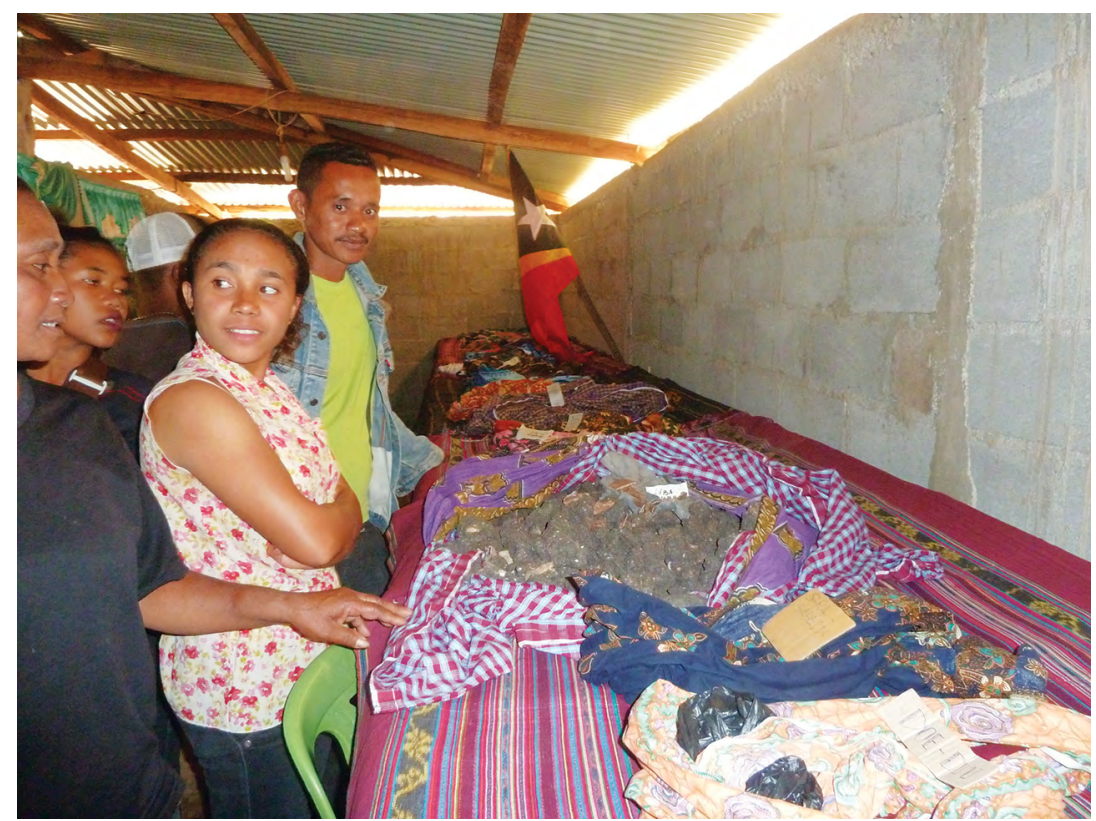

Photo 47: Collected bones and soil in their sarongs.

It soon became apparent, however, that something else was going on. On closer inspection from the veranda, I could see that there was not a coffin on the table as one would expect to find at a mate uma. Rather, there were a large number of bundled materials. We learned that these 23 sarongs contained the remains of this origin house's war dead. Each sarong was lain carefully along the length of the long tais-covered table. As we were later shown, each contained the actual bones-or rocks, as symbolic bones - of men, women and children who had died in the early years of the invasion. As the Indonesian troops took control of the area, many had fled across the valley or the relative safety of the Matebian mountains. Some were hunted and killed by the Indonesian military; others starved to death. Their bodies had never been recovered and laid to rest. Until now.

After recent consultation with the nature spirits, family members of the deceased had organised a bone-recovery party and, over a concerted two-month period, the party had followed a path down across the valley and into the forests of the Matebian range. The remains recovered on that journey had then been temporarily stored in the health clinic in the mountainous village of Kelikai. The day before our arrival, the Ministry of Health had provided an ambulance to transport the remains 
of the 23 deceased back to Ariana. The long journey from the Matebian mountains to the coast and back up again to Mount Ariana had taken it the best part of day.

Here at the house, they were laid out inside their sarongs on the table. As we were invited in to pay our respects, each sarong was carefully opened to reveal the name of the deceased written on a scrap of cardboard. I saw immediately that these were nearly all indigenous Timorese names; few had a Portuguese or Christian name. It was then that I understood our hosts' explanation of the scene. In two days' time, a Catholic priest would be attending the house to posthumously baptise each of these people. Their individual remains would then each be placed in the tiny chipboard coffins that many of the young men were busily making under the marquee out front. Each would be 'dressed' first, their clothes folded and placed along with their remains in the coffin. Two days later, the community would gather together in the graveyard overlooking Matebian for a full Catholic mass. A large grave with 23 separate compartments had already been prepared.

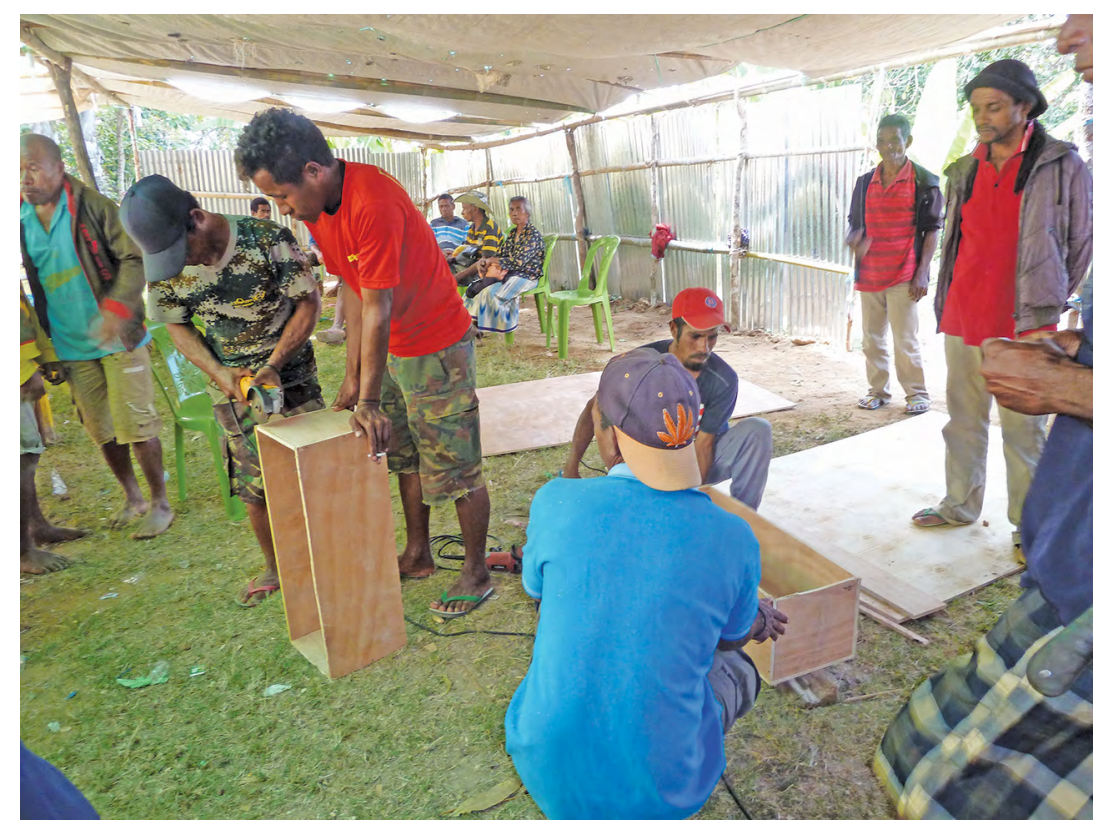

Photo 48: Making the burial coffins. 
I quickly abandoned my aim of interviewing the healer and suggested to Senhor Almeida that I would be happy to record anything those assembled would like to say. I offered to video the speakers and return it as a record of their commentary and of this event. Our hosts immediately agreed. It dawned on me then the reason the health clinic director had organised for us to visit the house on this particular day. He, too, is a member of this community and it was obvious that he and his family wanted their struggle recorded. My presence to them was not an inconvenience: it offered this house a chance that their story, and their determination to properly bury their war dead, would reach the wider world.

It was a palpably emotional time for everyone assembled there. The property was crowded with people, from the infirm to newborns. I could feel the powerful aura surrounding the task at hand and the determination, no matter the circumstances, to honour and respectfully lay to rest their relatives. The monument under construction outside the house commemorated two fallen heroes: FALINTIL fighters who had died in battle. For this process, they had support through the reparations available from the government-sponsored resistance veteran's fund. But the reburial of family members-ordinary victims of war-had fallen to the survivors of the conflict. One house, comprising more than 200 people, had 25 dead bodies to lay to rest.

As we sat with the men on the veranda, I was struck with a wave of emotion and an overwhelming sadness. I was not sure if I could go through with the interview. But this sorrow derives, in part, from somewhere else; it trains its wrath on the world that I customarily inhabit and that grants me great privileges. Here we were in an obviously impoverished community who were coming together to try to recover from the ravages of a period of war waged more than 40 years ago. My own country had covertly provoked and supported the invasion and occupation of East Timor. The guns used by the soldiers and the bombs dropped on this region were dropped by planes supplied by the US and UK governments, Australia's allies. Now, these distant Western powers congratulate themselves on overseeing Timor-Leste's independence and status as a new nation-state. At the same time, they increasingly express their exasperation at the lack of Timorese 'development' and capacity. Yet the people affected by these bloody campaigns continue to draw on their collective cultural capacity to try to deal with their loss and trauma and to move forward in the 
most intimate and physically connected way possible. Their everyday lives are a world away from the boardrooms where development experts seek advice on overcoming 'cultural barriers' to development.

I knew that I must push my emotions aside and recover my composure from the shock of this visceral and unexpected encounter with a 'post-conflict community' so as to begin the video recording. Once the camera was rolling, I could better appreciate the greater significance of the event. Far from being backward-looking, the intention is firmly trained on ensuring the prosperity and pathways of current and future generations. I realised, too, that although we would not be carrying out the expected interview with a 'healer', this event and recorded commentary were entirely about health and healing.

The burial of these physical remains is not the end of the journey. Rather, it opens a path forward into the future. It gives the living a way to continue with their own lives. As usual, the main concern was marriage relations between houses. Enabling and properly negotiating their own marriage arrangements would not be possible until the death arrangements of their parents and grandparents had been properly concluded. The exchanges between houses that surround a death ritual act to settle outstanding debts, to brings past events to a close at the same time as they create new paths and openings. But all of this requires a body to collectively grieve over and lay to rest. This process had not been possible. Until now.

The few days before the bodies were to be posthumously christened and then buried was especially important. After Senhor Almeida had presciently raised the topic, it was explained to me, on camera, that the family members of this and associated houses would come together and negotiate the past marriage arrangements of the deceased and settle any outstanding debts as a part of their burial. These exchanges, once concluded, would allow the deceased to transition out of the darkness and into the light. Catholic christening would also lead them to the light and was in accordance with contemporary societal expectations. Most importantly, in the next year's consecration of corn and rice following harvest, the deceased would take up their rightful places as the protectors of the living. Once properly buried, the names of the deceased can be called out at these annual agricultural rituals. They would be honoured as ancestors and asked to give their blessing and support to the living. Their spirits would now reside inside the house, the physical structure of which was located up the hill in the mountain peaks. 


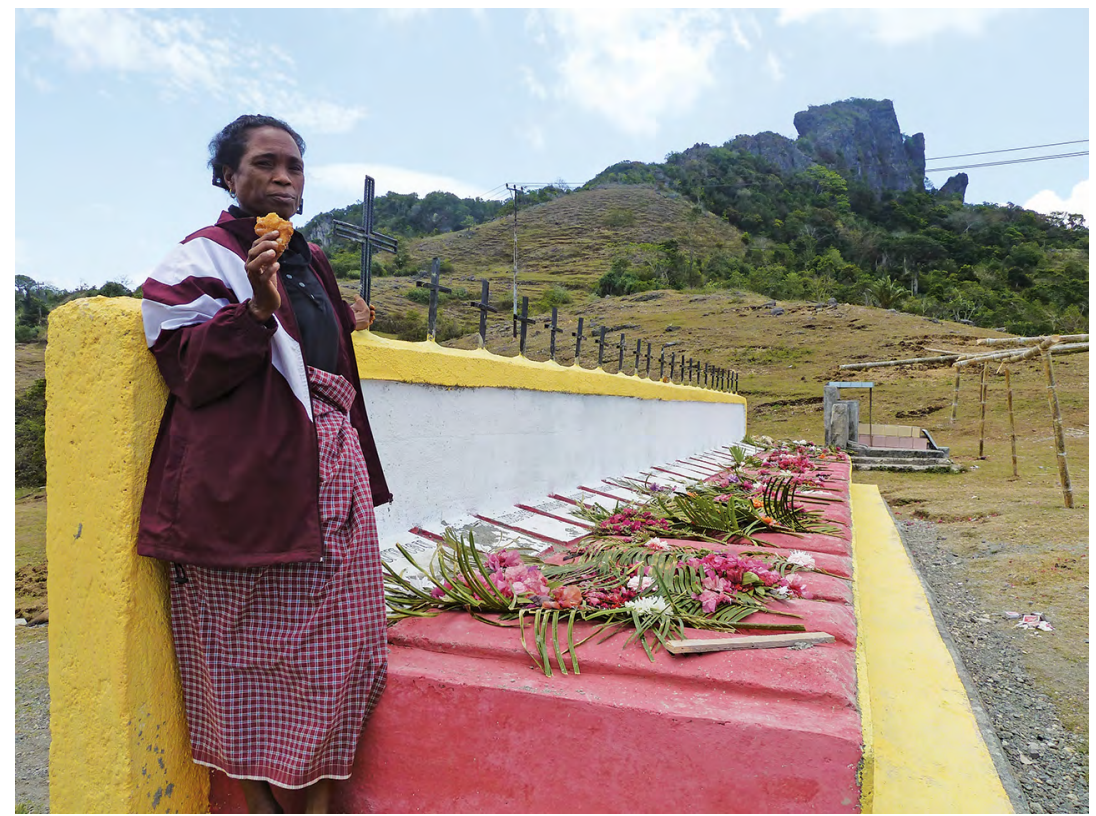

\section{Photo 49: The 23 grave compartments.}

Senhor Domingos, the healer, explained that the time before the priest's arrival were critical hours for the families to sit in communication with their loved ones. They would sit together 'in the darkness' and journey together through the ritual process that is required by the spirit realm. 'Then,' he said, 'we will hand them over to the priest for the next stage in their journey.'

Later, I told this story to Louisa, a sister-in-law in Baucau, and she was overcome by sadness for her own reasons. As a young child, Louisa, her mother and her baby sister had lived in the forests on the run for more than a year following the Indonesian invasions. Louisa's father had only managed to find them after he joined the Indonesian army as a porter. During their forest patrols, he used the opportunity to call out to his wife in Makasae. By some miracle, as his wife and children huddled together close to starvation in a small, forested cave, they heard him call to them and surrendered. Other family members were not so lucky. Many of their extended family died during this time. Their bodies had never been recovered. 'We didn't even find one,' she said, choking back tears. Across the country, similar bone-recovery and reburial processes have been completed or are underway. It is a process of intergenerational healing in which some have more success than others. 
On that day in Ariana, we wrapped up the commentary and filming of the process quite quickly and said our goodbyes. I felt rushed, but Quin was keen to leave. He had his own death business to attend to. An old man in the village had died and we had promised our family we would be back in time to join them in the visit to the mate uma.

On return to Bercoli, we gathered at one of the uncle's houses before travelling in convoy to the house of the deceased. We drove to the funeral with the back part of our car crammed full of young nieces and nephews. Quin called out to them that there was a competition to see who the best wailer was today. Our kids and I weren't sure if he was teasing or not. We unloaded our gifts-several sacks of rice, slabs of sweet drinks and carefully folded piles of tais - and were ushered into the front room of the tiny mud-floored house. The tais were added to the collection alongside of the coffin. The aunties and other older women in our group began the vigorous halele (ritual wail) over the coffin. With the release of this guttural wailing there was a surge of emotion in the room. Although they had participated in many such funerals, Madalena and Zeca looked disconcerted. It had been a strange day and it was humid and very hot in the small coffin-filled room. Our bodies were pressed tightly together and the smell of the deceased wafting from the coffin was overpowering. The wailing continued for some time as the others of us stood together and silently paid our respects. I comforted Zeca that we would soon be leaving, but then another party of mourners arrived and somehow squeezed into the room with us. The older women in this party did not take part in the halele. While some of the women from our party continuing to wail, the newcomers began instead to recite the rosary. All the other members of their party and the non-wailing members of our party joined in. It was both soothing and bedlam. Rosary prayers alternated with hymns. This seemed to go on forever and Zeca slipped away to play with the younger boys outside. Madalena was by then squashed deep in the far corner of the room with her girl cousins and couldn't move. Quin quipped later that we were lucky it was only five rounds of the rosary, not 10. Finally, silence descended, and we were all ushered out of the room so that other newly arrived groups of mourners could take our place.

We sat and chatted with fellow groups of mourners gathered outside before our group was escorted to the house next door. There, a marquee was erected, and dozens of large plates of meat were laid on the table. I noticed the many pigs, goats, horses and buffalo in the yards surrounding the property, and the makeshift kitchen full of people where the freshly 
slaughtered meat was being carved up. But it was not yet time to for our party to eat. The meat laid out on the table was pork for the fetosaa (fertility-taker) in-laws. After that, the goat and buffalo meat would be laid out for the umane (fertility-giver) in-laws. We were considered part of the house so we would eat last. We were asked to take refreshments in another area where the table was laid out with sweet drinks and cake. We were then ushered out again shortly after so the next party could take their seats and refreshments. While we waited for our meal to be served, we were asked to sit with the Old Man and some of the other senior men from the household and village. Others in our party went to help in the kitchen.

One of the men seated with us, Joao, was a catechist, the younger brother of the deceased. Presumably for the benefit of us as outsiders, people known to frown on the extravagance of Timorese death rituals, Joao noted disapprovingly that:

It is too much. There is the mate uma (death house ritual), the ai funan moruk and midar (two separate sweet and bitter flower rituals), the kore metan (end of mourning ritual) and then they open it all up again two or three years later for another final ritual. It should just be one ritual involving prayers from the priest. Our Timorese identity is linked to our houses and our agricultural rituals. Death should be left to the church.

From their muted reaction, it appeared that the other men seated with us did not agree, although they didn't say much at the time. Later, back at home, the Old Man told us that he and the others had spent the rest of the afternoon negotiating the outstanding debts of the houses linked to the deceased. One reason for this was that the mother of the deceased (who was also the mother of Joao, the catechist) had been buried several decades ago without rituals, negotiations or complicated exchanges. Because she had died during the early years of the Indonesian invasion, the people had simply returned to the village from the mountains, and the priest had given a simple blessing and that was all. But, as the Old Man said: 'That was then, and this is now'. With the death of her son, protocol and the health of future generations demanded that the negotiations held off during the war be reopened. The deceased's mother's business must be fully settled before they could properly bury her son and negotiate the outstanding arrangements between the various houses involved. Exchanges must be organised and gifted to the mother's family by her deceased husband and son's house before they could bury and talk 
about the processes involved in her son's funerary proceedings. The Old Man observed that Joao had looked very glum during the protracted negotiations. 'But he didn't say anything. These practices are our law.'

One day, two sets of ostensibly different death rituals. Yet what had transpired at the mate uma was essentially the same as what was occurring at the haloot ruin (bone-recovery ritual) in the mountains earlier in the day. The time elapsed since death and the presence of actual bodies may have varied, but both rituals were about ensuring that familial relations were in order, and that the pathways to healing were opened up so that the names of the dead could be properly honoured, and societal relations could continue to unfold. 
This text is taken from Island Encounters: Timor-Leste from the outside in, by Lisa Palmer, published 2021 by ANU Press, The Australian National University, Canberra, Australia.

doi.org/10.22459/IE.2021.12 